\title{
Bacterial contamination of intraocular lens surgery
}

\author{
GILLIAN C. VAFIDIS,' RONALD J. MARSH, ${ }^{1}$ AND ANDREW R. STACEY ${ }^{2}$ \\ From the 'Western Ophthalmic Hospital, Marylebone Road, London NW1, and the \\ 'Department of Medical Microbiology, Medical School, St Mary's Hospital, Praed Street, London W2
}

SUMMARY One hundred sterile intraocular lenses were placed on the external eye of 50 patients during cataract surgery. Half of the specimens were cultured for bacteria, the other half were examined under the light microscope after fixing and staining. A bacterial contamination rate of $26 \%$ was recorded. This is significantly higher than that found in conjunctival swabs $(6 \%)$ or irrigation specimens $(8 \%)$ taken at the same time, and higher than that recorded in a group of control lenses $(15 \cdot 2 \%)$ exposed to operating theatre air alone. We propose that intraocular lenses contaminated with viable bacteria may be implanted into the eye and thereby account for some cases of postoperative uveitis in the pseudophakic eye.

Postoperative infection is one of the most feared complications of intraocular lens implantation, and postoperative inflammation is an event which still eludes satisfactory explanation. There have been many suggestions: low-grade infections, ${ }^{\prime}$ excessive surgical manipulation with damage to intraocular tissues, irritation of iris and ciliary body by the lens, ${ }^{2}$ and finally leaching out of chemical irritants from the lens surface. ${ }^{3}$ The incidence of sterile hypopyon has been quoted as being as high as $2-3 \%$ in some series of intraocular lens implantation, ${ }^{45}$ and postoperative uveitis still occurs at a significant rate of up to $6 \%$. 'It may be difficult to control; indeed sometimes it may be necessary to remove the lens. ' In some cases inflammation is associated with infection by an organism of low pathogenicity, ${ }^{7}$ normally commensal in the conjunctival sac. ${ }^{8}$ Staphylococcus aureus (coagulasepositive) and Staph. epidermidis (coagulase-negative) are the bacteria most frequently encountered, and they can be cultured from tissue removed from the eye at the time of surgery."

Moreover it is possible that the intraocular lens may pick up bacteria from the external eye while being inserted and the internal eye is thus contaminated. Support for this idea comes from the demonstration of the adsorptive properties of the material from which most intraocular lenses are made: Polymethyl methacrylate (PMMA) is an acrylic polymer which carries an electrostatic charge, ${ }^{10}$ and this may account partially or fully for its adsorptive nature. Thatcher used this property " when employCorrespondence to Dr G. C. Vafidis, Moorficlds Eyc Hospital, City Road, London EC1V 2PD. ing small discs of PMMA to take cytology specimens from the conjunctiva, demonstrating a considerably higher yield of bacteria and epithelial and inflammatory cells than in the samples obtained from conjunctival scrapes or swabs. In the context of pseudophakic surgery this characteristic is a considerable hazard and may result in cellular debris, including live bacteria, being carried into the eye.

We designed a prospective trial to investigate whether such contamination of the intraocular lens by viable bacteria at the time of surgery might occur.

\section{Material and methods}

Fifty patients were included in the trial, being admitted for routine cataract surgery at the Western Ophthalmic Hospital between October 1982 and January 1983. 119 sterile intraocular lenses were used, of which 70 were sterilised by $10 \%$ sodium hydroxide (wet pack) and 50 by the ethylene oxide method (dry pack). They were of various designs, including Boberg-Ans, Sinsky, Choyce marks 8 and 9, Binkhorst, and Federov.

Patients were prepared for cataract surgery by having their lashes cut and given chloramphenicol $0.5 \%$ eye drops 4 times daily for 36 hours preoperatively to both eyes. On the day of the operation cyclopentolate $1 \%$ and phenylephrine $10 \%$ were instilled. The lids and skin surrounding the globe were cleaned with aqueous Hibitane (chlorhexidine) or iodine and Steridrape applied. The trial lenses were prepared as if for insertion into the eye but kept separate from those intended for implantation. 


\section{PROCEDURE}

After the lid speculum and superior rectus suture were placed, two conjunctival specimens were taken for culture as follows. Specimen 1: A moist cotton swab was smeared across the superior limbus and fornix and immediately placed in transport medium. Specimen 2: An irrigation specimen of the conjunctiva was obtained by irrigating the eye with balanced salt solution and aspirating $0.5 \mathrm{ml}$ from the lateral canthus into a sterile container. The specimens were sent for culture to the bacteriology department. Forty-seven cases had a limbus-based flap with corneoscleral section and three had corneal sections. The cataract was removed and the section temporarily closed prior to taking specimens 3 and 4 .

Specimen 3: A trial intraocular lens (IOL) was placed across the conjunctival flap and the section for 5 seconds. It was then removed and placed in ToddHewitt buffered glucose broth for culture. Specimen 4: A second trial IOL was similarly placed on the eye, transferred to a sterile watch glass to dry, and then placed in a dry sterile specimen jar for later staining and microscopy. All of the specimens were processed by one of us (A.R.S.). The lenses were fixed in methanol and stained with methylene blue (MerciaBrocades Ltd.).

The implant was then inserted as appropriate and the section closed. Postoperative medication in all cases included topical steroid and antibiotics (neomycin or chloramphenicol). The patients were assessed at day 2, day 5, at 3 weeks, and 3 months by the same clinician (G.C.V.) without prior knowledge of culture results. The degree of anterior chamber activity was graded $0-3+$ of cells, any hypopyon drawn, and the clarity of the red reflex graded 1-3.

As a control, to assess bacterial contamination from sources other than the eye we exposed 19 sterile lenses of the same mixed types ( 9 wet pack and 10 dry) and 10 bottles of broth to air in a clean theatre on separate occasions for approximately 10 seconds each. The lenses were then placed in Todd-Hewitt broth and all specimens were sent for culture.

\section{Results}

Fifty patients completed the trial. Extracapsular extraction was performed in 35 patients, the rest were intracapsular. Twenty-one patients had intraocular lenses inserted. Clinically no severe inflammatory reactions were observed in any of the 50 patients and no hypopyons. All patients had $2+$ of cells or less activity in the anterior chamber on discharge from hospital (5th postoperative day). At outpatient follow-up three weeks later 44 of the 50 showed minimal inflammatory activity with a grade 1 red reflex. There was no difference in activity between aphakic and pseudophakic eyes.

\section{BACTERIOLOGY}

Different specimens from 15 patients grew bacteria (see Tables 1, 2, and 3). All the contaminated samples were in the group that had limbus-based flaps with corneoscleral sections. Of the 23 positive cultures 20 were Staphylococcus epidermidis. The three other organisms were a Bacillus sp., a diphtheroid, and an alpha-haemolytic streptococcus. The antibiotic sensitivities of these organisms are shown on Table 4. Microscopy of the lenses (specimen 4) revealed

Table 1 Bacteriology and microscopy results in 50 patients

\begin{tabular}{|c|c|c|c|c|}
\hline Patient nos. & $\begin{array}{l}\text { Specimen I } \\
\text { (conjunctival swab) }\end{array}$ & $\begin{array}{l}\text { Specimen } 2 \\
\text { (irrigation fluid) }\end{array}$ & $\begin{array}{l}\text { Specimen } 3 \\
\text { (IOL in culture broth) }\end{array}$ & $\begin{array}{l}\text { Specimen } 4 \\
\text { (microscopy of IOL) }\end{array}$ \\
\hline $\begin{array}{l}2 \\
9\end{array}$ & $\begin{array}{l}\text { Staph. epidermidis } \\
\text { NG }\end{array}$ & $\begin{array}{l}\text { NG } \\
\text { NG }\end{array}$ & $\begin{array}{l}\text { NG } \\
7 \text { Staph. epidermidis } \\
1 \text { Staph. epidermidis } \\
\text { + Bacillus sp. } \\
1 \text { Diphtheroid sp. }\end{array}$ & $\begin{array}{l}18 \text { Ep. cells scanty } \\
11 \text { Ep. cclls } 1+ \\
6 \text { Ep. cclls } 2+ \\
2 \text { Ep. cells scanty } \\
3 \text { Ep. cells scanty } \\
3 \text { Ep. cclls } 1+ \\
2 \text { Ep. cclls } 2+ \\
1 \text { ? organism } \\
\text { Ep. cclls } 1+\end{array}$ \\
\hline \multirow[t]{3}{*}{3} & \multirow[t]{3}{*}{ NG } & \multicolumn{2}{|c|}{ Same antibiotic sensitivity pattern } & \\
\hline & & $\begin{array}{r}\text { I Staph. epidermidis } \\
\text { Different } \\
\text { I Staph. epidermidis } \\
\text { Different }\end{array}$ & $\begin{array}{l}\text { Staph. epidermidis } \\
\text { ic sensitivity pattern } \\
\text { Staph. epidermidis } \\
\text { ic sensitivity pattern }\end{array}$ & 2 Ep. cclls scanty \\
\hline & & $\begin{array}{l}\text { 1 Staph. epidermidis } \\
+ \text { Hacm. strep. }\end{array}$ & Staph. epidermidis & 1 Ep. cclls $1+$ \\
\hline 1 & $\begin{array}{l}\text { Staph. epidermidis } \\
2 \text { different biotypes }\end{array}$ & Staph. epidermidis & $\begin{array}{l}\text { biotypes } \\
\text { Staph. epidermidis }\end{array}$ & 1 Ep. cclls 1+ \\
\hline
\end{tabular}


Table 2 Numbers of specimens showing growth on culture

\begin{tabular}{lcc}
\hline Specimen showing grow'th & Nos. of patients & $\%$ \\
\hline 1. Intratocular Lens (spec. 3) & 13 & 26 \\
2. Irrigation (spec. 2) & 4 & 8 \\
3. Conjunctival swat (spec. 1) & 3 & 6 \\
\hline
\end{tabular}

Table 3 Patients showing growth in two or morespecimens

\begin{tabular}{lll}
\hline Combinations of positive specimens & Nos. of patients & $\%$ \\
\hline Specimens $3+2$ & 3 & 6 \\
Specimens $3+2+1$ & 1 & 2 \\
\hline
\end{tabular}

mainly epithelial cells. These were reported as scanty in $50 \%(25 / 50), 1+$ in $34 \%(17 / 50)$, and $2+$ in $16 \%$ $(8 / 50)$. In only one case was a possible organism seen on the lens. In four patients, both conjunctival (2) and lens specimens (3) grew bacteria (Table 1). However, in only one were the organisms possibly the same (identical antibiotic sensitivity being shown). Four patients with intraocular lens implantation had a positive result in one of the specimens, and three of these had quiet eyes with a visual acuity better than $6 / 12$ four months postoperatively. The fourth, who had an anterior chamber implant, had a visual acuity of $6 / 18$ four months after the operation with a persisting low grade panuveitis. In this patient specimen 1 grew Staphylococcus epidermidis; the other specimens were sterile. He was using dexamethasone $(1) .1 \%$ eye drops twice daily when seen in the outpatient department four months after operation.

From three of the 19 control lenses (one dry pack, two wet pack) we grew bacteria. Two were coagulasenegative staphylococci, the third a Bacillus sp. One of the 10 Todd-Hewitt broth specimens opened in the theatre as a control grew a mixture of Staph. aureus (coagulase-positive) and a Bacillus sp.

\section{Discussion}

The most remarkable aspect of these results is the lack of clinical inflammation recorded in the 50 eyes given the potentially high lens contamination rate with viable bacteria. There are three possible contri- butory factors: (1) the low virulence of bacteria involved, for example, Staphylococcus epidermidis; (2) the patient's own immunity against infection; (3) the postoperative medication of topical steroid and antibiotic.

Several potential sources of the bacterial contamination were found. The control lenses and broth are subject to two. Firstly, they may be already infected before being opened in the theatre, and secondly bacteria may have gained access while the Todd-Hewitt bottles and lenses were exposed to their brief handling in the theatre. The former is unlikely with modern methods of sterilising lenses. Ethylene oxide is a well proved technique, and $10 \%$ sodium hydroxide, although not accepted as a form of terminal sterilisation, is nevertheless bactericidal to the organisms found here. '? The second is eminently possible because the air in theatres is not sterile; thus three of the 19 lenses and one in 10 of the ToddHewitt broths were contaminated. A third source of contamination is by contact with the external eye during surgery (although there are not sufficient numbers to show if corneal sections are less contaminated). We have compared the numbers of contaminated specimens in the control and the manipulated lens groups and found them to be statistically different, the manipulated lenses showing more positive culture results than can be explained by their exposure to the operating theatre alone. However, these two groups are not numerically equivalent, and therefore any conclusions drawn from these figures must be considered provisional pending our further studies. Nevertheless the contamination rate in the trial lenses was higher than swab and irrigation specimens of the conjunctiva. This shows that the PMMA lens is indeed more effective at picking up bacteria, and we believe the external eye to be the most important source of organisms. The numbers are too small here to demonstrate any definite pattern between the bacteria isolated from the surface of the eye and those found on the trial lenses. The lack of findings on the stained preparations was to be expected, because it takes 10 organisms per $\mathrm{ml}$ to be detected in direct smear (Jones DB, personal communication) and we are dealing with very low concentrations of organisms here.

Table + Antibionic sensitivity of organisms cullured

\begin{tabular}{|c|c|c|c|c|c|}
\hline ()rganism & $\begin{array}{l}\text { Nos. of } \\
\text { specimens }\end{array}$ & ('hlorcamphenticol & (icnlumicin & Tetracycline & Ervthromycin \\
\hline Staph cepiclermiclis & $\begin{array}{r}15 \\
+1 \\
1\end{array}$ & $\begin{array}{l}S \\
S \\
R\end{array}$ & $\begin{array}{l}S \\
S \\
S\end{array}$ & $\begin{array}{l}S \\
R \\
S\end{array}$ & $\begin{array}{l}S \\
S \\
S\end{array}$ \\
\hline $\begin{array}{l}\text { Bacillus sp. } \\
\text { Diphtheroid } \\
\text { Hacm. strep. }\end{array}$ & $\begin{array}{l}1 \\
1 \\
1\end{array}$ & $\begin{array}{l}S \\
R \\
S\end{array}$ & $\begin{array}{l}S \\
S \\
R\end{array}$ & $\begin{array}{l}R \\
R \\
S\end{array}$ & $\begin{array}{l}S \\
S \\
S\end{array}$ \\
\hline
\end{tabular}


We are designing further experiments to investigate methods of reducing the likelihood of contamination from the operating theatre environment. A contributory factor must be the length of time that the lens is exposed prior to insertion into the eye, and this should be minimised by only taking the lens from its sterile container immediately before it is needed. This is possible with the dry pack lenses but clearly not applicable to the wet pack method, because of the need for 15 minutes' rinsing in sodium bicarbonate solution prior to use.

At insertion of an intraocular lens care must be taken to minimise contact with the external eye. If there is significant manipulation involving contact between the lens and the area around the section it would be safer to discard the contaminated lens in favour of a fresh one. Most firms provide a resterilisation service free of charge or for a nominal fee. In view of the high contamination rate we have shown in this paper we consider this safeguard might reduce the risk of intraocular inflammation in the pseudophakic eye.

We thank Rayner Intraocular Lens Ltd., Cilco Inc., and IOLAB for supplying the lenses used in the trial, Professor R. S. Fisher for statistical advice, and Ms C. Smyth for secretarial assistance.

\section{References}

I Schanzlin DJ, Goldberg DB. Brown SI. Staphylococcus epidermidis endophthalmitis following intraocular lens implantation. BrJ Ophthalmol 1980; 64: 684-6.

2 Keates RH. Ehrlich DR. 'Lenses of Chance': complications of anterior chamber implants. Ophthalmology 1978; 85: 408-14

3 Meltzer DW. Stcrile hypopyon following intraocular lens surgery. Arch Ophthalmol 1980); 98: $1(0)-4$.

4 Galin MA, Obstbaum SA, Boniuk V, Galin A, Silverstone D. Iris-supported lens implantation v. simple cataract extraction. Trans Ophthalimol Soc UK 1977; 97: 74-7.

5 Parelman AG. Sterile uveitis and intracular lens implantation. Am Intraocular lmplam Soc J 1979: 5: 301-6.

6 Drews RC. Inflammatory response endophthalmitis, corncal dystrophy, glaucoma, retinal detachment, dislocation, refractive crror. lens removal and enucleation. Ophthalmology 1978; 85: 164-75.

7 Eichenbaum DM. Jaffe NS. Clayman HM, Light DS. Pars plana vitrectomy as a primary treatment for acute bacterial endophthalmitis. Am J Ophuhulmol 1978: 86: 167-71.

$\therefore$ Smith (11. Bacteriology of the healthy conjunctiva. $\mathrm{Br} \mathrm{J} \mathrm{Op/l-}$ thalmol 1954: 38: 719-26.

9 Kohn AN. Bacterial cultures of lenses removed during cattaract surgery. Am J Ophthalmol 1978: 86: 162-6.

11) Ridley F. Safcty requirements for acrylic implants. $\mathrm{Br} J(\mathrm{Oph}$ thalmol 1957: 41: 359-67.

11 Thatcher RW. Conjunctival impression cytology. Arch Ophthalmol 1977: 95: 678-81.

12 (ialin MA. Turkish L. Sodium hydroxide sterilization of intraocular lenses. Am J ()phthalmol 1979: 88: 560)-4. 